\title{
Desain Interior untuk Menunjang Pembelajaran Interaktif dengan Nuansa Islam Studi Kasus MI Al - Huda
}

\author{
Arifa Tantri W. dan Aria Wenny A. \\ Departemen Desain Interior, Fakultas Arsitektur, Desain dan Perencanaan, Institut Teknologi Sepuluh \\ Nopember (ITS) \\ e-mail: aria.weny@yahoo.com,
}

\begin{abstract}
Abstrak-Pertumbuhan penduduk di Kota Malang menimbulkan kebutuhan akan sekolah meningkat. Di sisi lain agama merupakan hal penting yang perlu ditanamkan sejak dini karena merupakan sumber moral dan petunjuk kebenaran. Di sisi lain MI Al-Huda adalah salah satu sekolah Islam swasta yang ada di Kota Malang. Sekolah swasta memiliki perbedaan dari sekolah yang disediakan pemerintah karena sekolah swasta dimiliki olah perseorangan atau kelompok dan mendapatkan pendanaan dari pemerintah yang sangat sedikit, sehingga pendanaan operasional dibebankan pada wali murid. MI Al-Huda berdiri di atas lahan seluas $1160 \mathrm{~m}^{2}$ yang terbagi menjadi 2 bangunan utama dan digunakan untuk 18 ruang kelas, 2 ruang guru dan lain sebagainya. Sekolah tersebut memiliki masalah yaitu belum terlihatnya image atau citra sebagai sekolah Islam pada bangunan eksisting, oleh karena itu perlu adanya renovasi atau redesain. Redesain akan dilakukan dengan menyesuaikan karakter murid dan sistem pembelajaran yang dipakai. Guru menyampaikan $30 \%$ pembelajaran dengan cara kegiatan motorik seperti membuat karya dan games, sehingga disimpulkan bahwa guru menggunakan sistem pembelajaran interaktif karena model pembelajaran tersebut berorientasi atau terfokus pada murid. Redesain ini dilakukan dengan metode pengumpulan data dengan cara wawancara tidak terstruktur dan observasi, setelah data terkumpul dilanjutkan dengan analisa data. Hasil analisa data akan dijadikan sintesis dan dilanjutkan dengan perancangan desain, serta berakhir pada konsep desain. Konsep ini diharapkan dapat menyelesaikan masalah yang ada di MI Al-Huda.
\end{abstract}

Kata Kunci_Sekolah Islam, Sekolah dasar, Interior Islami.

\section{I.PENDAHULUAN}

$\mathrm{D}$ EWASA ini jumlah penduduk di kota Malang semakin meningkat, dibuktikan dengan data sensus pada tahun 2015 yang menyatakan bahwa jumlah penduduk kota Malang meningkat menjadi 881.754 jiwa dari 857.891 jiwa pada tahun 2014 [1], oleh karena itu kebutuhan akan fasilitas umum seperti sekolah semakin tinggi. Sekolah di Indonesia terbagi menjadi empat jenjang yaitu pendidikan anak usia dini, pendidikan dasar, dikan menengah dan pendidikan tinggi. Pendidikan dasar atau sekolah dasar yang disediakan pemerintah yaitu disebut Sekolah Dasar Negeri (SDN) dan Madrasah Ibtidaiyah Negeri (MIN) merupakan sekolah dengan kurikulum dan kebutuhan anak-anak umur 7-12 tahun, membedakan SDN dengan MIN yaitu tidak adanya tambahan kurikulum dari Kementerian Agama.

Sekolah tingkat dasar yang terdapat di kota Malang sejumlah 333 sekolah [2], yang terdiri dari SDN sejumlah 210,
Sekolah Dasar Swasta sejumlah 73, MIN sejumlah 2, MIS sejumlah 48. Salah satu MIS yang ada di Kota Malang adalah MI Al-Huda, sekolah tersebut berlokasi di kecamatan Kedungkandang, Sekolah tersebut dibangun di kawasan perumahan, sehingga murid yang bersekolah di MI Al-Huda adalah warga kecamatan Kedungkandang.

MI Al-Huda memiliki visi yaitu "Menjadi Institusi terdepan dalam Penanaman Karakter Islami dan Pancasila". MI AlHuda sebagai sekolah Islam swasta, memiliki masalah yaitu belum terlihatnya image Islam pada bangunan sekolah. Image Islam pada bangunan sebagian besar dibentuk dari budaya Islam pada zaman dahulu, seperti kaligrafi arab dan Islamic geometric pattern. Menurut Thames and Hudson (1995), perkembangan kaligrafi menandai bahwa perkembangan sastra di Islam sedang berkembang [3], sedangkan Islamic geometric pattern menandai bahwa perkembangan ilmu pengetahun sedang berkembang karena pembuatannya membutuhkan rumus matematika.

Bangunan sekolah berdiri di atas lahan seluas $1160 \mathrm{~m}^{2}$ yang dibagi menjadi dua bangunan dan digunakan untuk 18 ruang kelas, 2 ruang guru, 1 aula dan beberapa ruang lainnya. Beberapa kelas memiliki luasan yang berbeda-beda, seperti ruang kelas 4 yang memiliki luasan rata-rata terkecil yaitu 36 $\mathrm{m}^{2}$, hal tersebut tidak memenuhi luasan untuk murid dengan jumlah 26-27 orang, berdasarkan rasio minimum luas ruang kelas yang disaranakan adalah $2 \mathrm{~m}^{2} /$ murid $^{1}$ dan luasan ruang kelas harus disesuaikan dengan jumlah maksimal murid yaitu 28 murid dengan luas ruang kelas $58 \mathrm{~m}^{2}$ [4]. Di sisi lain terdapat penelitian yang menyebutkan bahwa fasilitas yang kurang baik seperti furnitur yang tidak sesuai ukuran, pintu yang sulit dibuka, ruang kelas atau dinding koridor tanpa karya murid, hal tersebut dapat membuat murid merasa tidak disambut [5], sehingga proses belajar mengajar kurang efektif karena murid tidak bahagia saat di sekolah.

MI Al-Huda memiliki 458 murid yang terbagi dalam tiga kelas tiap angkatannya, tiap angkatan memiliki proses belajar mengajar yang berbeda, disesuaikan dengan umur murid. Guru menggunakan berbagai cara dalam proses belajar mengajar seperti melalui kegiatan yang melibatkan motorik, kegiatan tersebut dapat berupa games ataupun membuat karya. Pada realisasinya $30 \%$ penyampaian materi dilaksanakan melalui kegaitan motorik, sehingga dapat disimpulkan bahwa guru menerapkan pembelajaran interaktif karena model pembelajaran tersebut berorientasi atau terfokus pada murid. 
Tabel 1.

The key operational elements of the teaching space

\begin{tabular}{lcccc}
\hline \hline & $\begin{array}{c}\text { Number } \\
\text { of pupils }\end{array}$ & $\begin{array}{c}\text { Work } \\
\text { method }\end{array}$ & $\begin{array}{c}\text { Processing } \\
\text { method }\end{array}$ & $\begin{array}{c}\text { Type of } \\
\text { workspace }\end{array}$ \\
\hline $\begin{array}{l}\text { Reflective } \\
\text { learning } \\
\text { environment }\end{array}$ & $1-2$ & $\begin{array}{c}\text { Individual } \\
\text { or pair work }\end{array}$ & $\begin{array}{c}\text { Personal } \\
\text { processing }\end{array}$ & $\begin{array}{c}\text { Personal } \\
\text { workstation }\end{array}$ \\
$\begin{array}{l}\text { Creative } \\
\text { learning } \\
\text { environment }\end{array}$ & $4-6$ & $\begin{array}{c}\text { Small group } \\
\text { work }\end{array}$ & $\begin{array}{c}\text { Group } \\
\text { processing }\end{array}$ & $\begin{array}{c}\text { Flexible } \\
\text { workstation }\end{array}$ \\
$\begin{array}{l}\text { Interactive } \\
\text { learning } \\
\text { environment }\end{array}$ & $20-40$ & $\begin{array}{c}\text { Large group } \\
\text { work }\end{array}$ & $\begin{array}{c}\text { Democratic } \\
\text { group } \\
\text { procesing }\end{array}$ & $\begin{array}{c}\text { Flexible and } \\
\text { changeable } \\
\text { workspace }\end{array}$ \\
\hline \hline
\end{tabular}

Operasional yang disarankan untuk Area Mengajar (2017)

Sumber: The Future of the Physial Learning Environment

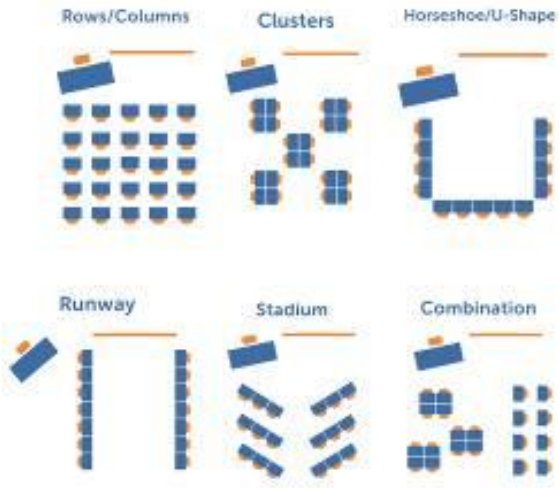

Gambar 1. Konfigurasi bangku murid (2017).

Sumber: The Future of the Physial Learning Environment.

Dari pemaparan yang sudah disebutkan pada paragraf sebelumnya, MI Al-Huda membutuhkan fasilitas pendidikan yang mampu mendukung proses belajar interaktif dan beberapa program sekolah lainnya, oleh karena itu dilakukan perbaikan atau renovasi dan penataan ulang pada sekolah. Perencanaan desain harus memperhatikan beberapa hal seperti aspek ergonomik sebagai faktor ekonomis, kenyamanan dan keamanan pengguna, selain itu juga menerapkan warna-warna dan bentuk yang terinspirasi dari Islam sehingga mampu meningkatkan image sekolah Islam.

A. Rumusan Masalah

1. Bagaimana menciptakan desain sekolah yang mendukung pembelajaran interaktif?

2. Bagaimana menambahka citra atau image sekolah Is lam melalui bentuk yang terinspirasi dari Islam?

B. Tujuan

1. Menghasilkan desain sekolah yang mendukung pembelajaran interaktif

2. Menghasilkan desain sekolah yang memiliki image atau citra sekolah islam melalui bentuk yang terinspirasi dari Islam

\section{II.TINJAUAN PUSTAKA}

\section{A. Sekolah}

Menurut Yusuf, sekolah merupakan lembaga pendidikan formal yang secara sistematis melaksanakan program bimbingan, mengajar dan latihan dalam rangka membantu siswa agar mampu mengembangkan potensinya, dalam aspek moral, spiritual, intelektual, emosional, maupun sosial [6], sedangkan menurut Winkel, sekolah merupakan lingkungan

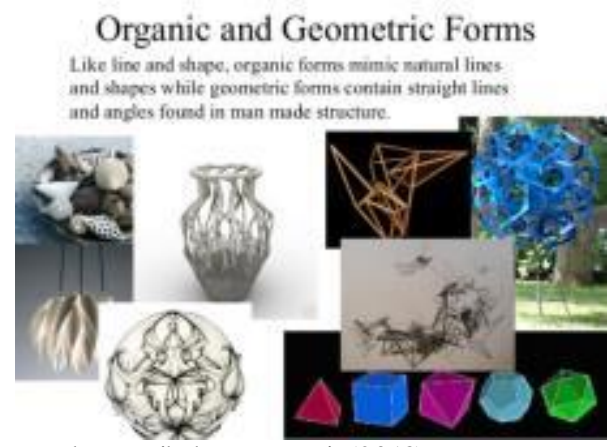

Gambar 2. Bentuk organik dan geometris (2018) Sumber: Pinterest

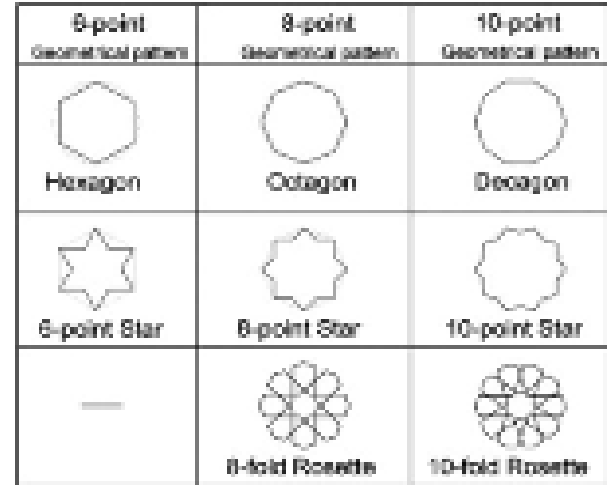

Gambar 3. Operasional yang disarankan untuk Area Mengajar (2017) Sumber: Pinterest.

pendidikan formal. Dikatakan formal karena di sekolah terlaksana serangkaian kegiatan terencana dan terorganisasi, termasuk kegiatan dalam rangka proses belajar mengajar di kelas [7].

Madrasah adalah lembaga pendidikan yang menjadikan mata pelajaran agama Islam sebagai mata pelajaran dasar yang diberikan sekurang-sekurangnya $30 \%$ di samping mata pelajaran umum [8]. Kemenag (Kementerian Agama) membuat aturan mengenai kompetensi dasar, yang digunakan untuk pengaplikasiannya dalam proses belajar mengajar. Kompetensi Inti ini bukan untuk diajarkan melainkan untuk dibentuk melalui proses belajar mengajar. Beban belajar dan struktur kurikulum pada di MI Al-Huda sudah sesuai dengan peraturan pemerintah, dapat dibuktikan dengan jam dan mata sekolah yang sudah sesuai.

\section{B. Model Pembelajaran Interaktif}

Pembelajaran Interaktif adalah suatu cara atau teknik pembelajaran yang digunakan guru pada saat menyajikan bahan pengajaran yaitu guru sebagai pemeran utama dalam menciptakan situasi interaktif yang edukatif [9]. Komponenkomponen pembelajaran ditinjau dari pendekatan sistem, dalam prosesnya suatu pembelajaran akan melibatkan berbagai komponen, diantaranya: tujuan, guru, peserta didik, materi, metode, media serta evaluasi [10].

Lingkungan belajar yang interaktif dibutuhkan area belajar yang fleksibel dan changeable [11]. Kondisi eksisting MI AlHuda belum sepenuhnya mendukung pembelajaran interaktif, hal tersebut bisa dilihat dari bentuk meja dan kursi murid yang memiliki desain yang cukup sulit untuk dipindahkan, sehingga sulit untuk digunakan ketika ada tugas kelompok di dalam ruang kelas. (Tabel 1) 


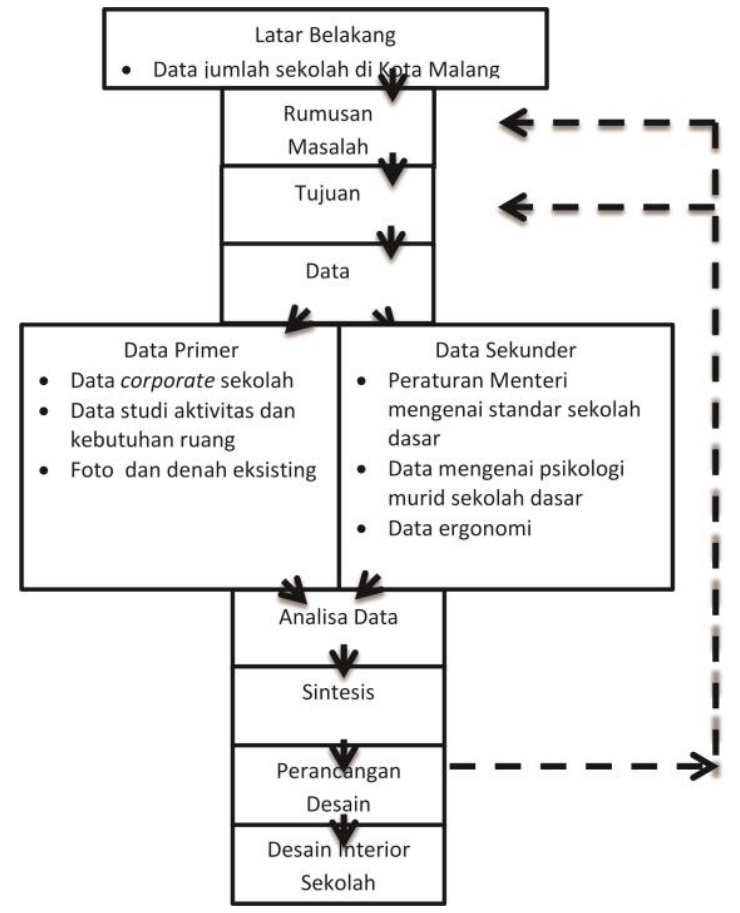

Gambar 5. Bagan Metode Penelitian (2017).

Sumber: Dokumentasi Penulis

\section{Kajian Mengenai Fasilitas Sekolah}

Ruang kelas merupakan tempat dimana murid dan guru melaksanakan proses belajar mengajar, furnitur harus ditata sedemikian rupa sehingga proses belajar mengajar dapat berjalan optimal. Terdapat beberapa konfigurasi atau susunan meja dan kursi dalam kelas, yaitu; traditional rows or column, clusters / group, u-shape, runway, stadium, dan kombinasi yang penerapan konfigurasinya disesuaikan dengan model pembelajaran dan karakteristik murid dalam ruang kelas [12]. (Gambar 1)

D.Kajian mengenai Pertumbuhan danPerkembangan Masa Kanak-KanakAkhir

Masa kanak-kanak akhir merupakan anak pada usia 6 tahun sampai masuk ke masa pubertass dan masa remaja awal yang berkisar usia 11- 13 tahun. Pertumbuhan fisik cenderung lebih stabil atau tenang sebelum memasuki masa remaja yang pertumbuhannya cukup cepat. Kenaikan tinggi dan berat badan bervariasi antara anak yang satu dengan yang lain.

Perkembangan kognitif menggambarkan bagaimana kemampuan berfikir anak berkembang dan berfungsi. Kemampuan berfikir anak berkembang dari tingkat yang sederhana dan konkret ketingkat yang lebih rumit dan abstrak. Pada masa ini anak sudah dapat memecahkan masalahmasalah yang bersifat konkret atau melalui pengalaman langsung.

Perkembangan bahasa pada masa kanak-kanak akhir dipengaruhi oleh 2 faktor yaitu kematangan pada organ-organ yang berfungsi untuk berbicara dan proses belajar [13].

Perkembangan moral ditandai dengan kemampuan anak untuk memahami aturan, norma dan etika yang berlaku di masyarakat. Di sisi lain pengembangan moral seperti nilainilai agama merupakan hal yang sangat penting dalam membentuk sikap dan kepribadian anak. Mengenalkan anak

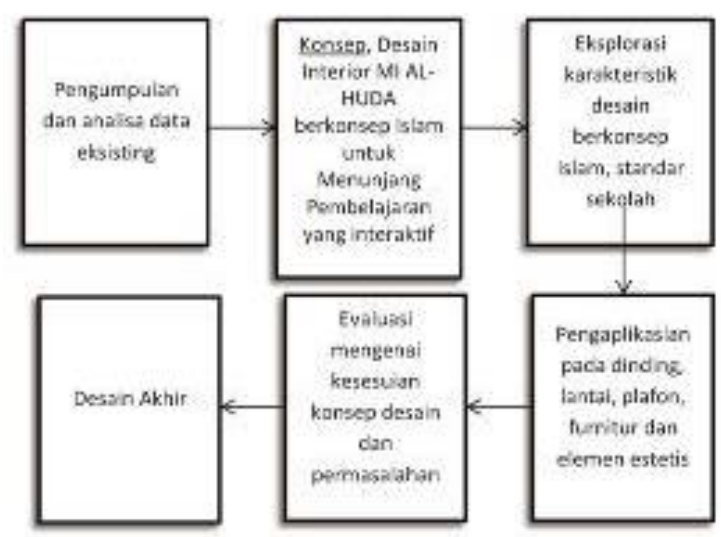

Gambar 6. Bagan Proses Desain (2017)

pada nilai-nilai agama dan memberikan pengarahan terhadap anak tentang hal-hal yang terpuji dan tercela [14].

\section{E. Kajian Mengenai Bnetuk dan Wujud}

Bentuk dapat dibagi menjadi 2 yaitu bentuk organic dan geomtris. Bentuk organik adalah bentuk yang cenderung tidak beraturan dan sebagian besar asimetris Contoh dari bentuk organic dan geometris ditunjukkan pada Gambar 2.

\section{F. Islamic Geomtetry Design}

Islamic Geometry Pattern merupakan motif yang sering digunakan untuk mendesain sesuatu yang memiliki unsur Islam, contohnya yaitu pada bangunan. Perkembangan motif ini didasari oleh perkembangan ilmu pengetahuan dan teknologi pada abad ke 8 - 9 di daerah timur tengah seperti Iran dan daerah Central Asia [15].

Islamic Geometriy Pattern adalah motif yang tak tehingga jika disusun dan ha tersebut menggambarkan tak terbatasnya Allah Yang Maha Kuasa [16]. Terdapat beberapa macam tipe Islamic Geometriy Pattern yaitu 6 point, 8 point dan 10 point. (Gambar 3)

\section{G. Studi Eksisting}

MI Al-Huda dibangun di atas 2 komplek tanah dengan luasan tanah pertama seluas $1160 \mathrm{~m} 2$ berlokasi di depan dan tanah kedua seluas $460 \mathrm{~m} 2$ berlokasi di belakang. Kedua tanah ini dipisahkan oleh jalan kecil selebar 2,8m yang hanya bisa dilewati kendaraan roda 2 dan pejalan kaki. Tanah seluas 1620 $\mathrm{m} 2$ digunakan untuk 3 jenjang pendidikan yaitu TK (Taman Kanak-kanak), MI (Madrasah Ibtidaiyah) dan MTs (Madrasah Tsanawiyah). Secara keseluruhan gedung menghadap qiblat. (Gambar 4)

\section{METODOLOGI PENELITIAN}

\section{A. Bagan Proses Desain}

Bagan Proses Desain di tunjukkan pada Gambar 5.

\section{B. Metode Pencarian Data}

Metode pengumpulan data yang digunakan dalam perancangan ini adalah sebagai berikut:
a. Observasi,
b. Wawancara, dan
c. Literatur 


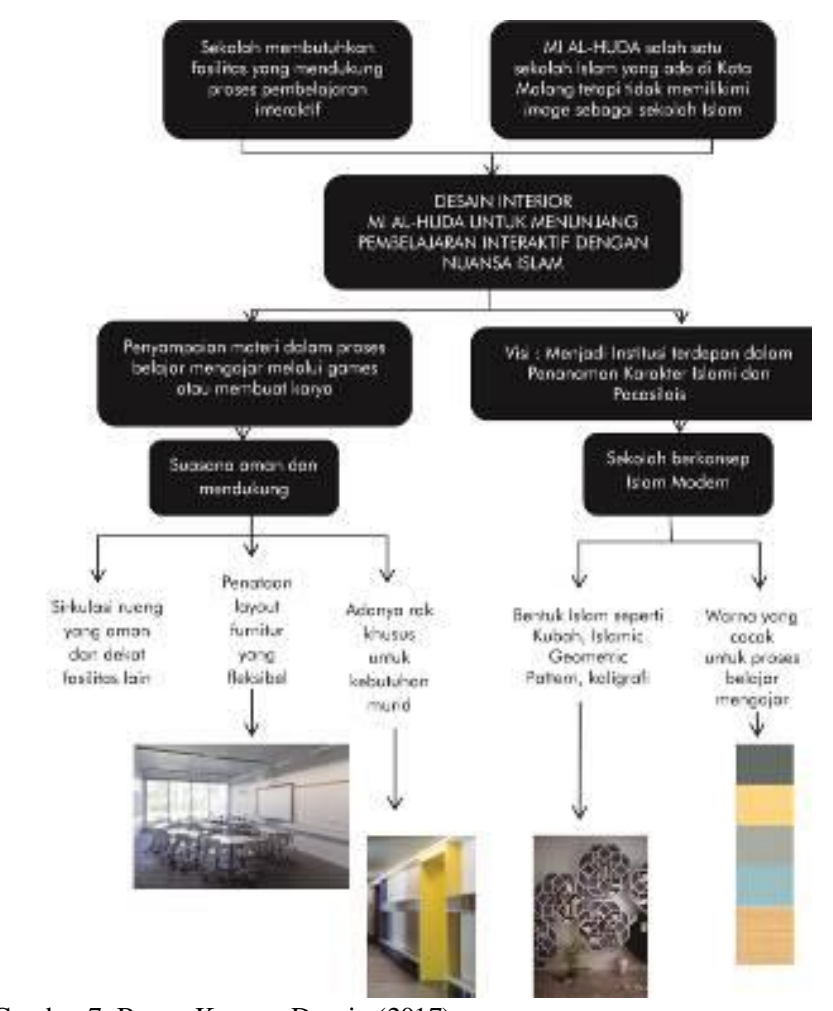

Gambar 7. Bagan Konsep Desain (2017).

Metode yang sudah disebutkan berfungsi untuk mengumpulkan data mengenai sekolah dan artikel terkait, sehingga aktivitas dan kebutuhan anak di sekolah dapat diketahui.

\section{Tahap Analisa Data}

Analisa data merupakan salah satu proses dalam perancangan ini. Hal ini dilakukan setelah data primer dan sekunder terkumpul. Beriktu adalah beberapa poin yang akan dianalisa oleh penulis :

a. Analisa pengguna, yaitu analisa mengenai pengguna mengenai segmen umur, gender dan karakter pengguna di MI Al-Huda

b. Analisa aktivitas, yaitu analisa mengenai aktivitas pengguna yang akan dihubungkan dengan analisa kebutuhan ruang dan furnitur

c. Analisa sirkulasi, yaitu analisa mengenai area yang digunakan sebagaialur lalu lalang.

d. Analisa pencahayaan dan penghawaan, yaitu analisa mengenai pencahayaan dan penghawaaan yang ada di MI Al-Huda dan pengaruhnya terhadap kenyamanan pengguna

e. Analisa material, yaitu analisa mengenai material yang digunakan pada bangunan MI Al-Huda dan pengaruhnya terhadap kenyamanan dan keamanan pengguna

f. Analisa warna, yaitu analisa mengenai warna yang digunakan pada bangunan MI Al-Huda dan pengaruhnya terhadap image atau citra sekolah dan psikologis pengguna

\section{E. Tahap Desain}

Bagian proses desain ini ditunjukkan pada Gambar 6 .

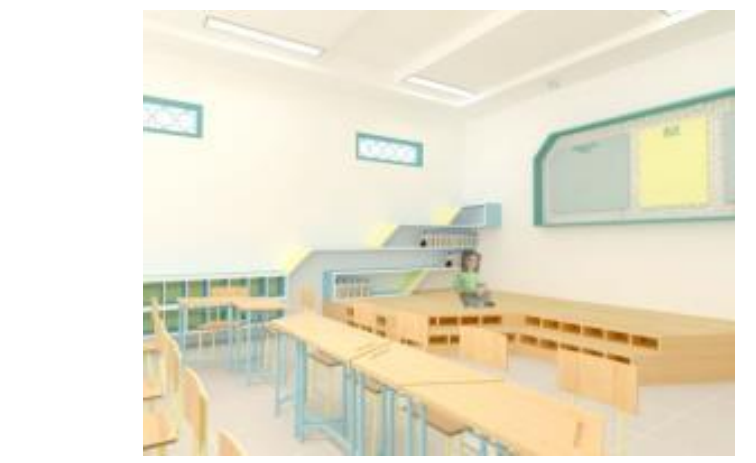

Gambar 8. Gambar 3D Render Ruang Kelas 2.

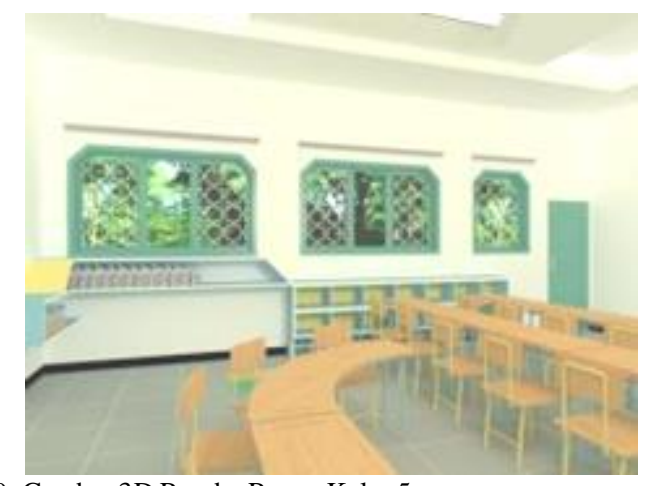

Gambar 9. Gambar 3D Render Ruang Kelas 5.

\section{ANALISIS DAN PEMBAHASAN}

\section{A. Analisa Pengguna}

a. Murid

Murid MI AL-Huda adalah anak yang berusia sekitar 6-12 tahun. Karakteristik murid secara garis besar dibagi menjadi 3 yaitu murid kelas 1 dan; murid kelas 3; dan murid kelas 4-6. Ketiga kelompok tersebut memiliki jam belajar yang berbeda.

b. Guru

Guru MI AL-Huda adalah karyawan yang bertugas sebagai pengajar dan pendidik murid MI Al-Huda. Jumlah guru di MI AL-Huda sebanyak 32 orang yang berusia sekitar 30-45 tahun.

c. Kepala sekolah

d. Ketua Yayasan

e. Wali murid atau Tamu sekolah

Wali murid atau Tamu sekolah adalah orang eksternal sekolah yang hanya menggunakan fasilitas sekolah tertentu dalam jangka waktu tertentu pula.

Untuk kebutuhan ruang dapat dilihat pada Tabel 2.

\section{B. Konsep Desain}

Bagan konsep ini ditunjukkan pada Gambar 7.

\section{PROSES DAN HASIL DESAIN}

\section{A. Pengembangan Desain Ruang Kelas 2}

Ruangan pertama yang akan dikembangkan desainnya adalah ruang kelas 2 , hal tersebut dikarenakan desain ruang kelas 2 mewakili desain ruang kelas untuk kelas $1-3$. 
Tabel 2.

Analisa kebut uhan ruang

\begin{tabular}{|c|c|c|c|}
\hline No & Pengguna & $\begin{array}{l}\text { Luas Kebutuhan } \\
\text { Furnitur }\left(\mathrm{m}^{2}\right)\end{array}$ & Luas Kebut uhan Total $\left(\mathrm{m}^{2}\right)$ \\
\hline 1 & $\begin{array}{l}\text { Ruang } \\
\text { Kelas 2 }\end{array}$ & $\begin{array}{l}\text { Murid=15.13 } \\
\text { Guru }=4.51 \\
\text { L.Furni } \\
=15.13+4.51 \\
=19.64\end{array}$ & $\begin{array}{l}=\text { L.Furni }: \text { L.Sirkulasi } \\
=1: 2 \\
\text { L.Sirkulasi }=39.28 \\
\text { Luas Kebut uhan Total } \\
=\text { L.Furni + L. Sirkulasi } \\
=58.92\end{array}$ \\
\hline 2 & $\begin{array}{l}\text { Ruag Kelas } \\
5\end{array}$ & $\begin{array}{l}\text { Murid =14.66 } \\
\text { Guru =4.51 } \\
\text { Furnitur } \\
=14.66+4.51 \\
=19.17\end{array}$ & $\begin{array}{l}=\text { L.Furni }: \text { L.Sirkulasi } \\
=1: 2 \\
\text { L.Sirkulasi }=38.34 \\
\text { Luas Kebutuhan Total } \\
=\text { L.Furni + L. Sirkulasi } \\
=57.51\end{array}$ \\
\hline 3 & $\begin{array}{l}\text { Perpustaka } \\
\text { an }\end{array}$ & $\begin{array}{l}\text { Murid = } 13.06 \\
\text { Guru }=1.58 \\
\text { Furnitur } \\
=13.06+1.58 \\
=14.64\end{array}$ & $\begin{array}{l}=\text { L.Furni }: \text { L.Sirkulasi } \\
=1: 2 \\
\text { L.Sirkulasi }=29.28 \\
\text { Luas Kebut uhan Total } \\
=\text { L.Furni + L.Sirkulasi } \\
=43.92\end{array}$ \\
\hline
\end{tabular}

Dalam kegiatan belajar interaktif membutuhkan layout yang fleksibel sehingga model pembelajaran tidak hanya terfokus pada guru menjelaskan di depan. Beberapa model pembelajaran membutuhkan konfigurasi bangku murid

a. Konfigurasi semi circle atau u-shape yaitu konfigurasi ketika membutuhkan banyakdiskusi dan presentasi

b. Konfigurasi cluster tersbut cocok untuk proses belajar berkelompok. Konfigurasi cluster ini dibagi menjadi 2 yaitu konfigurasi kelompok ketika 1 kelompok berisi 4-5 orang murid, sedangkan konfigurasi ketiga adalah konfigurasi kelompok ketika 1 kelompok berisi 3-4 orang murid.

Proses pengembangan desain selanjutnya adalah pembuatan gambar 3d. Berikut adalah hasil dari gambar 3d yang sudah dirender. (Gambar 8)

\section{B. Pengembangan Desain Ruang Kelas 5}

Ruangan kedua yang akan dikembangkan desainnya adalah ruang kelas 5 , hal tersebut dikarenakan desain ruang kelas 5 mewakili desain ruang kelas untuk kelas $4-6$. Layout furnitur yang sudah dibuat memiliki salah satu kelebihan yaitu bisa dirubahnya konfigurasi meja dan kursi menjadi konfigurasi berkelompok.

Proses pengembangan desain selanjutnya adalah pembuatan gambar 3d. Berikut adalah hasil dari gambar 3d yang sudah dirender. (Gambar 9)

\section{Pengembangan Desain Ruang Terpilih 3}

Ruangan terakhir yang akan dikembangkan desainnya adalah ruang perpustakaan, hal tersebut berdasarkan tingkat kebutuan perpustakaan di MI Al-Huda tidak sebanding dengan fasilitas yang ada. Pemakaian perspustakaan pada jam pelajaran disesuaikan dengan jadwal yang dibuat oleh pihak perpustakaan, sedangkan pada saat di luar jam pelajaran murid bebas menggunakan perpustakaan.

Layout ruang persputakaan dibagi menjadi 4 aera yaitu area peminjaman buku atau resepsionis, area multimedia, area membaca buku dan area penyimpanan buku. Pengelompokkan area tersebut berdasarkan dengan kegiatan dan kebutuhan pengguna. Proses pengembangan desain selanjutnya adalah

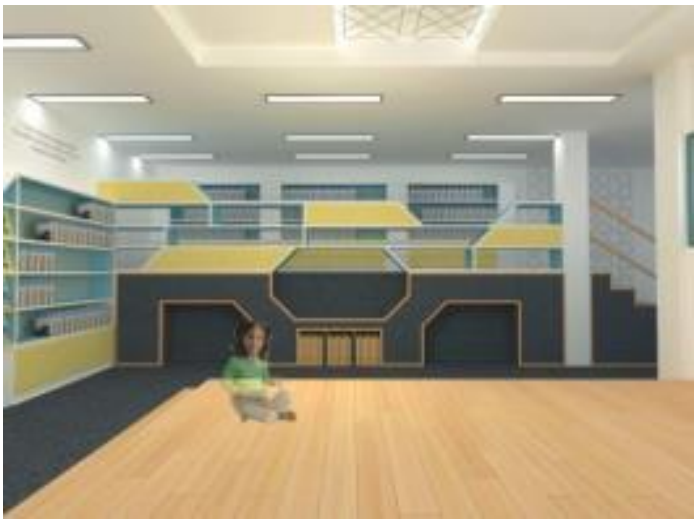

Gambar 10. Gambar 3D Render Ruang Perpustakaan.

pembuatan gambar 3d. Berikut adalah hasil dari gambar 3d yang sudah di-render. (Gambar 10)

\section{KESIMPULAN}

Dari pembahasan mengenai Desain Interior MI Al-Huda untuk Menunjang Pembelajaran Interaktif dengan Nuansa Islam dapat diambil beberapa kesimpulan, antara lain :

1. Jumlah sekolah Islam harus diimbangi dengan pertumbuhan jumlah penduduk sehingga sekolah dapat tersebar rata.

2. MI Al-Huda adalah sekolah dasar Islam yang berlokasi di Kota Malang. Sekolah tersebut memiliki fasilitas penunjang pembelajaran yang kurang efektif, selain itu tidak terlihatnya citra sebagai sekolah Islam pada bangunan, sehingga perlu adanya redesain.

3. Fasilitas sekolah yang tidak terdesain dengan baik akan mengganggu psikologi murid

4. Pemilihan ruang kelas 2 dan ruang kelas 5 dikarenakan 2 desain ruang kelas tersebut bisa dijadikan acuan bagi jenjang lainnya

5. Fasilitas belajar pada ruang kelas 2 disesuaikan dengan kebutuhan murid kelas 1-3, sedangkan fasilitas belajar pada ruang kelas 5 disesuaikan dengan kebutuhan murid kelas 4-6.

6. Pada ruang perpustakaan dibagi menjadi 4 area yaitu area peminjaman buku atau resepsionis, area baca, area penyimpanan buku dan area multimedia yang masing-masing didesain sesuai dengan ergonomi murid TK hingga MTs.

7. Penambahan nuansa islami pada ruang kelas dan ruang perpustakaan menggunakan Islamic Geometry Design yang diaplikasikan pada elemen estetis.

\section{DAFTAR PUSTAKA}

[1] Pemerintah Kota Malang, "Laporan Kinerja Tahun 2015 Kota Malang," Malang, 2015.

[2] Dinas Pendidikan Kota Malang, "Daftar sekolah tingkat SD/MI/SDLB Kota Malang," Malang, 2017.

[3] Thames and Hudson, Architecture of the Islamic World . London, 1995.

[4] Menteri Pendidikan, "Peraturan Menteri Pendidikan Nasional Nomor 24 Tahun 2007," 2007.

[5] M. Lorraine and C. Emily, "Enviromental Personalization and Elementary School Childen's self-esteem," J. Enviromental Psychol., vol. 28, 2007. 
[6] Yusuf, Pendekatan Keterampilan Bagaimana Mengaktifkan Pesenta didik dalam Belajar. Jakarta: Gramedia, 2001.

[7] Winkel, "Hubungan Pemanfaatan Lingkungan Sekolah Sebagai Sumber Belajar Dengan Hasil Belajar Matematika Siswa Kelas III SDN 76/1 Sungai Buluh," 2009.

[8] Menteri Pendidikan dan Kebudayaan, Menteri Dalam Negeri, and Menteri Agama, "Surat Keput usan Bersama 3 Menteri," 1975.

[9] Hidayat, "Model Pembelajaran Interaktif," www.mediabelajar.info, 2013. [Online].

Available: http://www.mediabelajar.info/2013/06/model-model-pembelajaraninteraktif.html.

[10] Feridi, "Pembelajaran Interaktif," 2015. [Online]. Available: http://feridi.blog.upi.edu/2015/08/08/pembelajaran-interaktif.

[11] M. Kuuskorpi and N. C. González, The Future of the Physical Learning Environment: School Facilities that Support the User",
CELE Exchange, Centre for Effective Learning Environments. Paris: OECD Publishing, 2011.

[12] Anonymous, "EffectiveClassroom Seating Arrangements," 2017. [Online]. Available: http://www.displays2go.com/Article/EffectiveClassroom-Seating-Arrangements-32, diunduh $20 \mathrm{~J}$ September 2017.

[13] S. Yusuf, Psikologi Perkembangan Anak dan Remaja . Bandung: Remaja Rosdakarya, 2004.

[14] R. E. Izzati, "Perkembangan Peserta Didik,"2007.

[15] The Metropolitan Museum of Art, Islamic Art and Geometric Design. New York: Yale University Press, 2004.

[16] R. Othman and Z. Abidin, The Importance of Islamic Art in Mosque Interior. Kuala Lumpur, 2011. 